\title{
Tungsten mine waste geopolymeric binder: Preliminary hydration products investigations
}

\author{
Fernando Pacheco-Torgal $^{\mathrm{a}, *}$, João Castro-Gomes ${ }^{\mathrm{b}, 1}$, Said Jalali ${ }^{\mathrm{c}, 2}$ \\ ${ }^{a}$ Castelo Branco Polytechnic Institute, Department of Civil Engineering, 6000 Castelo Branco, Portugal \\ ${ }^{\mathrm{b}}$ University of Beira Interior, Department of Civil Engineering, 6200 Covilhã, Portugal \\ ${ }^{\mathrm{c}}$ University of Minho, Department of Civil Engineering, 4800 Guimarães, Portugal
}

Received 22 January 2007; received in revised form 3 January 2008; accepted 9 January 2008

Available online 21 February 2008

\begin{abstract}
Geopolymeric mine waste mud (GMWM) binders are obtained from dehydroxylated waste powder mixed with minor quantities of calcium hydroxide, activated with $\mathrm{NaOH}$ and waterglass solutions. In this work recent investigations of GMWM binders hydration products have been carried out. The hydration products have been investigated by means of X-ray diffraction (XRD) and scanning electron microscopy/energy dispersive spectroscopy (SEM/EDS).

Results indicate that mechanical strength as a function of the concentration of the alkaline activator is closely related to the mineralogy of the hardened geopolymeric binder. Results show that a new crystalline phase, phlogopite a trioctahedral layered structure, was formed as a result of the geopolymerization process. SEM and EDS analysis indicates that the hydration products were alkali aluminosilicate gel and calcium silicate hydrates.
\end{abstract}

(C) 2008 Elsevier Ltd. All rights reserved.

Keywords: Geopolymeric binder; Mine waste mud; Hydration products; Calcium silicate hydrates; Aluminosilicate gel

\section{Introduction}

Alkali activated cementitious systems were first investigated by Glukhovsky, who emphasized the difference between the composition of Portland cement, CSH and $\mathrm{Ca}(\mathrm{OH})_{2}$ and the composition of basic earth crust minerals, represented by zeolitic materials containing alkalis [1]. Earlier investigations on alkaline cements focused on alkali-activation of blast furnace slag with a mild alkaline solution. The main reaction product is, in that case, hydrated calcium silicates, like $\mathrm{CSH}$ gel with low $\mathrm{C} / \mathrm{S}$ ratio and in some cases the formation of crystalline phases like hydrotalcite $\left(\mathrm{Mg}_{6} \mathrm{Al}_{2} \mathrm{CO}_{3}(\mathrm{OH})_{16} 4 \mathrm{H}_{2} \mathrm{O}\right.$ has been reported

\footnotetext{
* Corresponding author. Tel.: +351 272 339300; fax: +351 272339399.

E-mail addresses: fernandotorgal@est.ipcb.pt (F. Pacheco-Torgal), castro.gomes@ubi.pt (J. Castro-Gomes), said@civil.uminho.pt (S. Jalali).

${ }^{1}$ Tel.: +351 275 329990; fax: +351275329969.

${ }^{2}$ Tel.: +351 253 510200; fax: +351253510213.
}

$[2,3]$. Some researchers have even reported that zeolite-like minerals were found in the hardened alkali-slag cement paste [4]. Davidovits developed and patented alkaline cements called "geopolymers". The polymerisation process involves a chemical reaction under highly alkaline conditions on $\mathrm{Al}-\mathrm{Si}$ minerals yielding $\mathrm{X}$-ray amorphous polymeric $\mathrm{Si}-\mathrm{O}-\mathrm{Al}-\mathrm{O}$ bonds with empirical formula $\mathrm{Mn}\left[-\mathrm{Si}_{-}\right.$ $\left.\left.\mathrm{O}_{2}\right)_{z}-\mathrm{Al}-\mathrm{O}\right]_{n} . w \mathrm{H}_{2} \mathrm{O}$, where $n$ is the degree of polymerization, $z$ is 1,2 or 3 , and $\mathrm{M}$ is an alkali cation, such as potassium or sodium $[5,6]$. Some geopolymers are similar to amorphous zeolites in which the crystallization stage is not reached due to the very fast reaction rates during the dissolution and condensation step and [7]. In some systems natural zeolites like sodalite and hydroxysodalite have been detected, using respectively metakaolin and fly ash systems $[8,9]$. Zeolites are members of a mineral class call tectosilicates, crystalline aluminosilicates with a three dimensional framework structure based on repeated units of $\mathrm{SiO}_{4}$ and $\mathrm{AlO}_{4}$ tetrahedra, containing alkaline and alkaline earth 
metal cations such as $\mathrm{Na}^{+}, \mathrm{K}^{+}, \mathrm{Ca}^{2+}$ and $\mathrm{Mg}^{2+}$ that maintain charge neutrality.

Recent investigations suggest that it is possible to have geopolymeric gel and calcium silicate hydrate $(\mathrm{CSH})$ gel formed simultaneously within a single system and that would increase the resultant compressive strength $[10,11]$ which contributes to the importance of more investigations on geopolymerization of aluminosilicate and calcium hydroxide mixtures.

Much of the work on geopolymeric systems use byproducts such as blast furnace slag or fly ash, due to the fact that those precursors don't need grinding operations or thermal treatment $[8,12]$. So far few studies have focused on the geopolymerization of industrial wastes and, knowing that the composition of raw precursors will determine the structure of the geopolymer hardening products, one may expect very different hydrated compounds from the one already investigated. Previous research has already showed the potential of using dehydroxylated tungsten mine waste mud mix with calcium hydroxide as raw material to the development of a high early strength geopolymeric binder [13-15]. This new binder shows a very good performance when compared with current commercial repair products, both mechanically as well as economically [16].

The objective of the present paper is, therefore, to present findings related to the hydration products of GMWM binders.

\section{Experimental program}

\subsection{Materials}

Tungsten mine waste mud used in this study was subject to a thermal treatment at $950{ }^{\circ} \mathrm{C}$ during $2 \mathrm{~h}$. The chemical composition of the mine waste mud is shown in Table 1. Table 2 shows gradation and physical characteristics of aggregates.

\subsection{Synthesis}

In this investigation the mortar was a mixture of aggregates, binder (waste mud and calcium hydroxide), alkaline

Table 1

Chemical composition

\begin{tabular}{ll}
\hline Constituents (\%) & $\begin{array}{l}\text { Dehydroxylated mine } \\
\text { waste mud }\end{array}$ \\
\hline $\mathrm{SiO}_{2}$ & 53.48 \\
$\mathrm{Al}_{2} \mathrm{O}_{3}$ & 16.66 \\
$\mathrm{Fe}_{2} \mathrm{O}_{3}$ & 12.33 \\
$\mathrm{~K}_{2} \mathrm{O}$ & 7.65 \\
$\mathrm{Na}$ & 0.62 \\
$\mathrm{MgO}$ & 1.27 \\
$\mathrm{SO}_{4}$ & 3.10 \\
$\mathrm{TiO}_{2}$ & 1.39 \\
$\mathrm{As}$ & 1.28 \\
Other minor oxides & 2.22 \\
\hline
\end{tabular}

Table 2

Gradation and physical characteristics of aggregates

\begin{tabular}{lll}
\hline & \multicolumn{2}{l}{ Cumulative percentage retained } \\
\cline { 2 - 3 } & $\begin{array}{l}\text { Schist }(\mathrm{SC}) \\
\text { Sand }\end{array}$ & $\begin{array}{l}\text { Granite }(\mathrm{GR}) \\
\text { Coarse aggregate }\end{array}$ \\
\hline $9.5 \mathrm{~mm}$ & 0 & 0 \\
$4.76 \mathrm{~mm}$ & 0 & 62.9 \\
$2.38 \mathrm{~mm}$ & 0.9 & 89.1 \\
$1.19 \mathrm{~mm}$ & 28.3 & 99.3 \\
$590 \mu \mathrm{m}$ & 62.2 & 99.4 \\
$297 \mu \mathrm{m}$ & 88.8 & 99.4 \\
$149 \mu \mathrm{m}$ & 98.7 & 99.7 \\
$74 \mu \mathrm{m}$ & 99.8 & 99.8 \\
Dust content $(<74 \mu \mathrm{m})$ & 0.2 & 0.2 \\
Fineness modulus & 2.78 & 5.5 \\
Max. dimension $(\mathrm{mm})$ & 2.38 & 9.52 \\
Water absorption $(\%)$ & 0.9 & 0.8 \\
Density $\left(\right.$ Kg $\left./ \mathrm{m}^{3}\right)$ & 2703 & 2659 \\
\hline
\end{tabular}

silicate solution and extra water. Previous investigations showed, that when using an activator with sodium hydroxide $(24 \mathrm{M})$ and sodium silicate solution $\left(\mathrm{Na}_{2} \mathrm{O}=8.6 \%\right.$, $\mathrm{SiO}_{2}=27.8 \%, \mathrm{Al}_{2} \mathrm{O}_{3}=0.4 \%$ and water $\left.=63.2 \%\right)$ with a mass ratio of 1:2,5, (waterglass modulus of 1.34) and calcium hydroxide with a percentage substitution of $10 \%$. The composition of the mixtures is given in Table 3. The mass ratio of mine waste mud: activator was 1:1. Distilled water was used to dissolve the sodium hydroxide flakes to avoid the effect of unknown contaminants in the mixing water. The alkaline activator was prepared prior to use. The sand, mine waste mud and calcium hydroxide were dry mixed before being added to the activator. To produce a workable mix extra water has been added. The mass ratio of water/dry solid content was $4 \%$. The fresh mortar or paste were cast and allowed to set at room temperature for $24 \mathrm{~h}$ before being removed from the moulds and kept at room temperature until tested in compression.

\subsection{Strength testing, $X$-ray diffraction, scanning electron microscopy and microanalysis}

Compressive strength data was obtained using $50 \times$ $50 \times 50 \mathrm{~mm}^{3}$ cubic specimens according to ASTM C109. Compressive strength for each mixture was obtained from an average of 3 cubic specimens determined at the age of 1 , $3,7,14,28$ and 56 days of curing.

A Rigaku Geigerflex diffractometer using $\mathrm{CuK} \alpha$ radiation was used for mineralogical characterization. In examination by scanning electron microscopy (SEM) mortar samples were embedded into a low viscosity epoxy resin, cut and polished. After the lapping stage an additional epoxy impregnation was performed, and the samples were relapped in order to ensure full resin impregnation and a good quality polish. The samples were then carboncoated. A Hitachi S2700 scanning electron microscope was used, equipped with a solid backscattered detector and a Rontec energy dispersive (EDS) X-ray microanalysis system. 
Table 3

Mixture composition and strength

\begin{tabular}{|c|c|c|c|c|c|c|c|}
\hline Analysis & Mixture & Aggregate & $\begin{array}{l}\text { Aggregate/binder } \\
\text { ratio }\end{array}$ & $\mathrm{Ca}(\mathrm{OH})_{2}(\%)$ & $\mathrm{NaOH}$ concent. & $\begin{array}{l}\mathrm{H}_{2} \mathrm{O} / \mathrm{Na}_{2} \mathrm{O} \\
\text { molar ratio }\end{array}$ & $\mathrm{fc}_{56}(\mathrm{MPa})$ \\
\hline \multirow[t]{5}{*}{ Strength XRD } & $\mathrm{SC} 1$ & Schist & 2.0 & 10 & $16 \mathrm{M}$ & 13.4 & 30.1 \\
\hline & $\mathrm{SC} 2$ & Schist & 2.0 & 22.5 & $14 \mathrm{M}$ & 14.6 & 16.5 \\
\hline & GR & Granite & 1.5 & 10 & $24 \mathrm{M}$ & 10.8 & 85.5 \\
\hline & PCP & - & - & 10 & $24 \mathrm{M}$ & 9.7 & 45.5 \\
\hline & LS & Limestone & 1.5 & 10 & $24 \mathrm{M}$ & 10.8 & 65.3 \\
\hline \multirow[t]{4}{*}{ SEM EDS } & $\mathrm{P} 13$ & Schist & 0.7 & 5 & $24 \mathrm{M}$ & 10.2 & 63.2 \\
\hline & $\mathrm{P} 7$ & Schist & 1.0 & 25 & $24 \mathrm{M}$ & 10.7 & 47.6 \\
\hline & $\mathrm{P} 25$ & River sand & 1.0 & 10 & $24 \mathrm{M}$ & 10.3 & 75.0 \\
\hline & P19 & River sand & 1.5 & 10 & $24 \mathrm{M}$ & 10.8 & 65.0 \\
\hline
\end{tabular}

\section{Results and discussion}

\subsection{Mineralogical and chemical composition}

Mineralogical composition of mine waste mud was muscovite and quartz which were identified by their characteristic patterns as follows: muscovite (card 46-1409) and quartz (card 46-1045). Muscovite is a dioctahedral layered structure in which a sheet of octahedral $\mathrm{Al}$ ions is sandwiched between two sheets of linked $\mathrm{SiO}_{4}$ tetrahedral with a general formula $\mathrm{KAl}_{2}\left(\mathrm{Si}_{3} \mathrm{Al}\right) \mathrm{O}_{10}(\mathrm{OH})_{2}$. The figures in Table 1 clearly show that mine waste mud consists essentially of silica and aluminium, contaminated with arsenic and sulphur and with a high content of iron and potassium oxide, which is one of the factors having a significant correlation with compressive strength of geopolymers based minerals. The $\mathrm{SiO}_{2} / \mathrm{Al}_{2} \mathrm{O}_{3}$ atomic ratio is 5.5 higher than the optimum suggested by Davidovits of about 2 to make cement and concrete. However the final $\mathrm{SiO}_{2} / \mathrm{Al}_{2} \mathrm{O}_{3}$ atomic ratio in the hardened binder depends mainly on the reactivity of Al-Si because not all the silica and alumina are reactive. Indeed most of the Al-Si materials cannot even supply sufficient $\mathrm{Si}$ in alkaline solution to start geopolymerization, this explains why they need extra silica provided in solution by waterglass, which influences the $\mathrm{Si} / \mathrm{Al}$ ratio of the hardened binder.

\subsection{Compressive strength}

Compressive strength of geopolymeric mine waste mud (GMWM) binders is shown in Fig. 1.

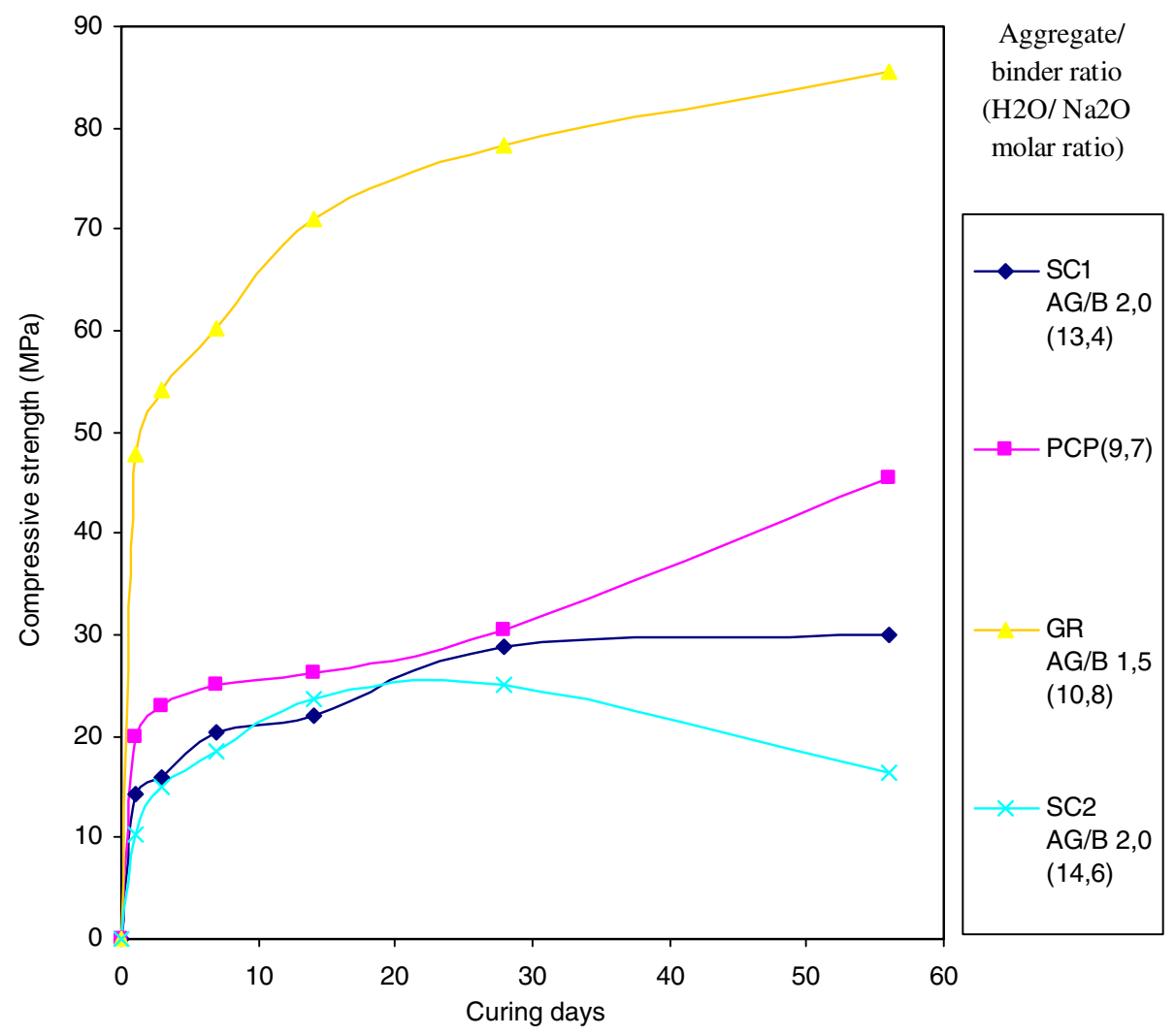

Fig. 1. Compressive strength according to curing age. 
Compressive strength behaviour is strongly related to $\mathrm{H}_{2} \mathrm{O} / \mathrm{Na}_{2} \mathrm{O}$ molar ratio. Increasing $\mathrm{NaOH}$ concentration provides better dissolution of silicate and aluminate species leading to increased inter-molecular bond strength. The $\mathrm{H}_{2} \mathrm{O} / \mathrm{Na}_{2} \mathrm{O}$ molar ratio is a parameter having a better relation to mixture composition than sodium hydroxide concentration alone. In fact as aggregate volume in the mixture increases more extra water is required to keep a minimum level of workability, so to the same sodium hydroxide concentration different aggregate volumes have different final $\mathrm{H}_{2} \mathrm{O} / \mathrm{Na}_{2} \mathrm{O}$. However, it must be taken into account the fact that mixtures with no aggregates as PCP, although they have a $\mathrm{H}_{2} \mathrm{O} / \mathrm{Na}_{2} \mathrm{O}$ molar ratio lower than the one of the mixture GR, they present lower

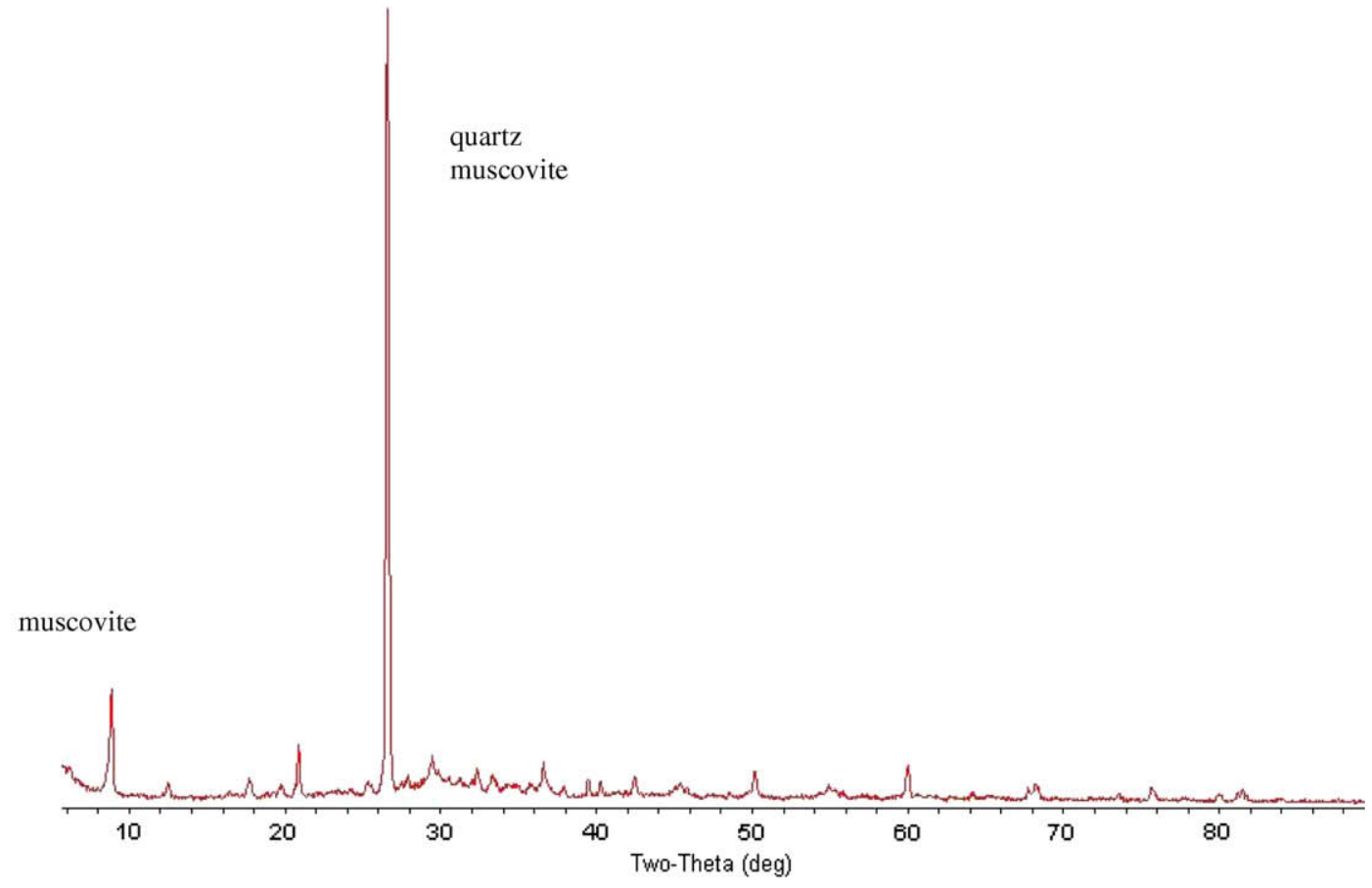

Fig. 2. XRD pattern of SC2 mortar with schist aggregates and $22.5 \%$ of calcium hydroxide activated with waterglass and $14 \mathrm{M} \mathrm{NaOH}$ solution.

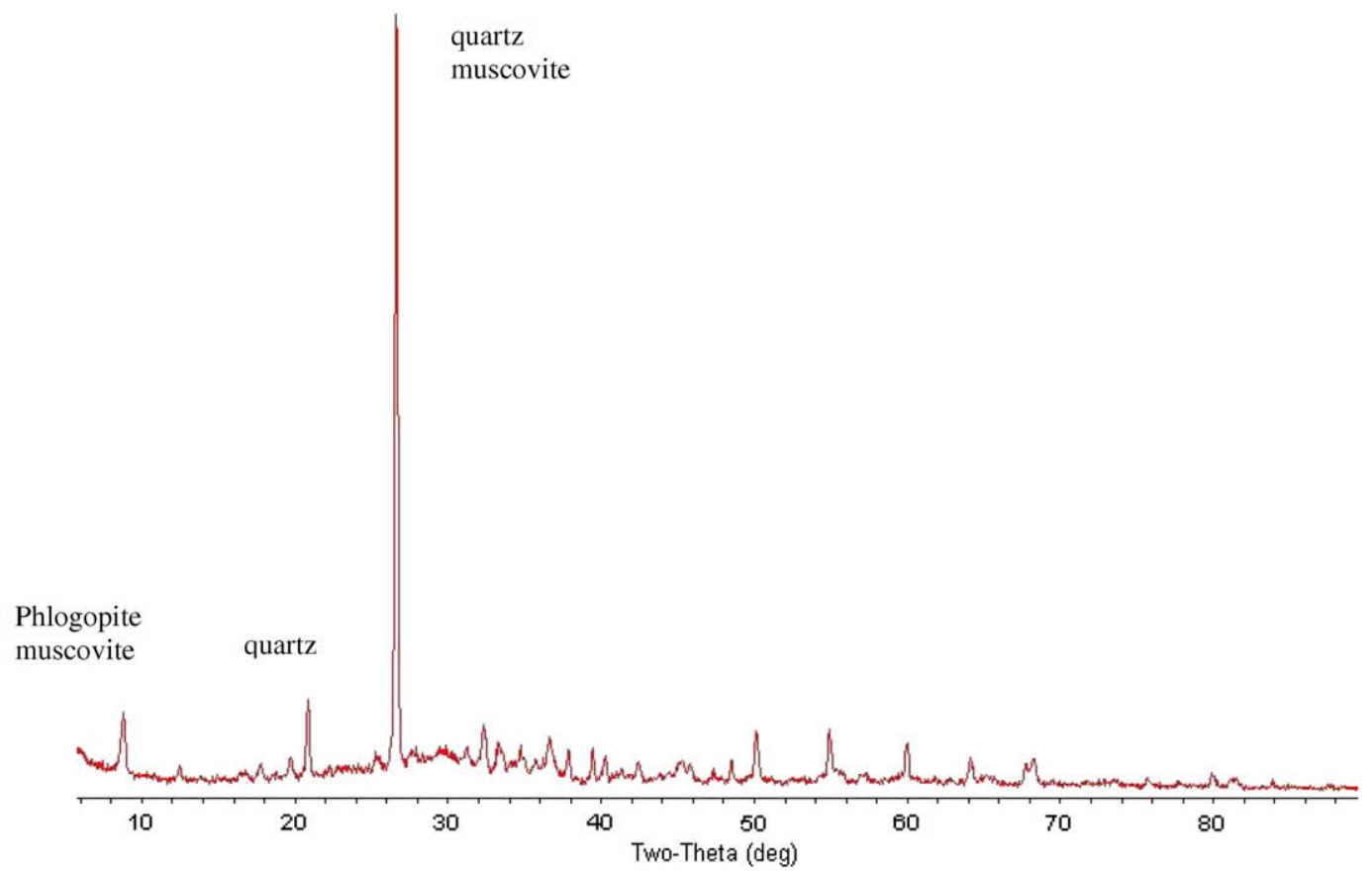

Fig. 3. XRD pattern of SC mortar with schist aggregates and $10 \%$ calcium hydroxide activated with waterglass and $16 \mathrm{M} \mathrm{NaOH}$ solution. 
strength. The authors suggested that can be explained by the active role played by the aggregates in the mixtures when subject to a high alkaline medium, due to ions species dissolved from the aggregates surfaces which greatly influence the geopolymerization process. The mixture $\mathrm{SC} 2$ (22.5\% of calcium hydroxide) presents decreasing strength after 28 days curing, it has been suggested that is due to a high level of calcium hydroxide percentage substitution because high hydroxyl concentration is hindered by the calcium hydroxide dissolution, so an increase in calcium hydroxide leads to minor reactant species dissolved. An alternative explanation has to do with the possibility of

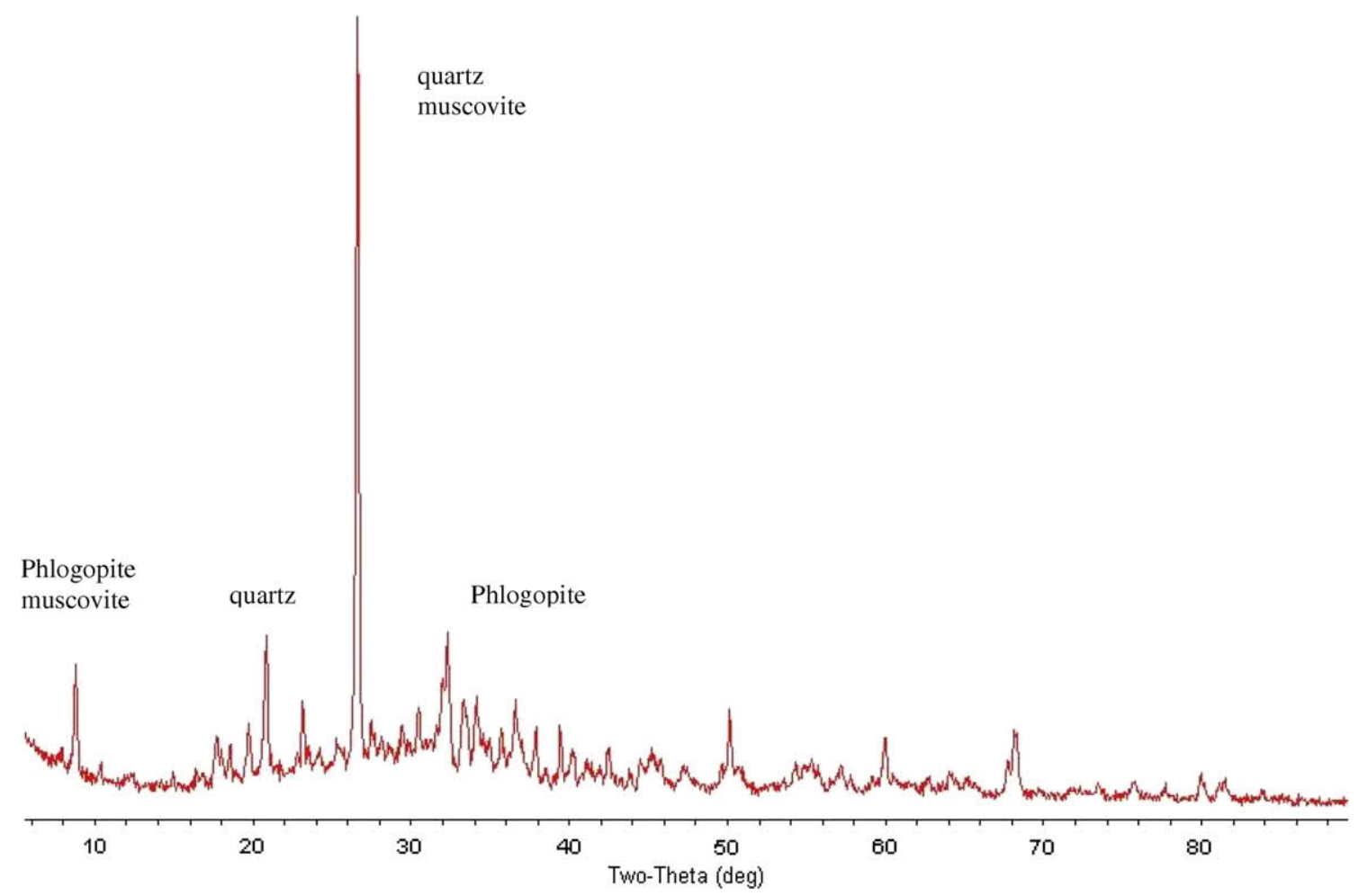

Fig. 4. XRD pattern of PCP paste with $10 \%$ calcium hydroxide activated with waterglass and $24 \mathrm{M} \mathrm{NaOH}$ solution.

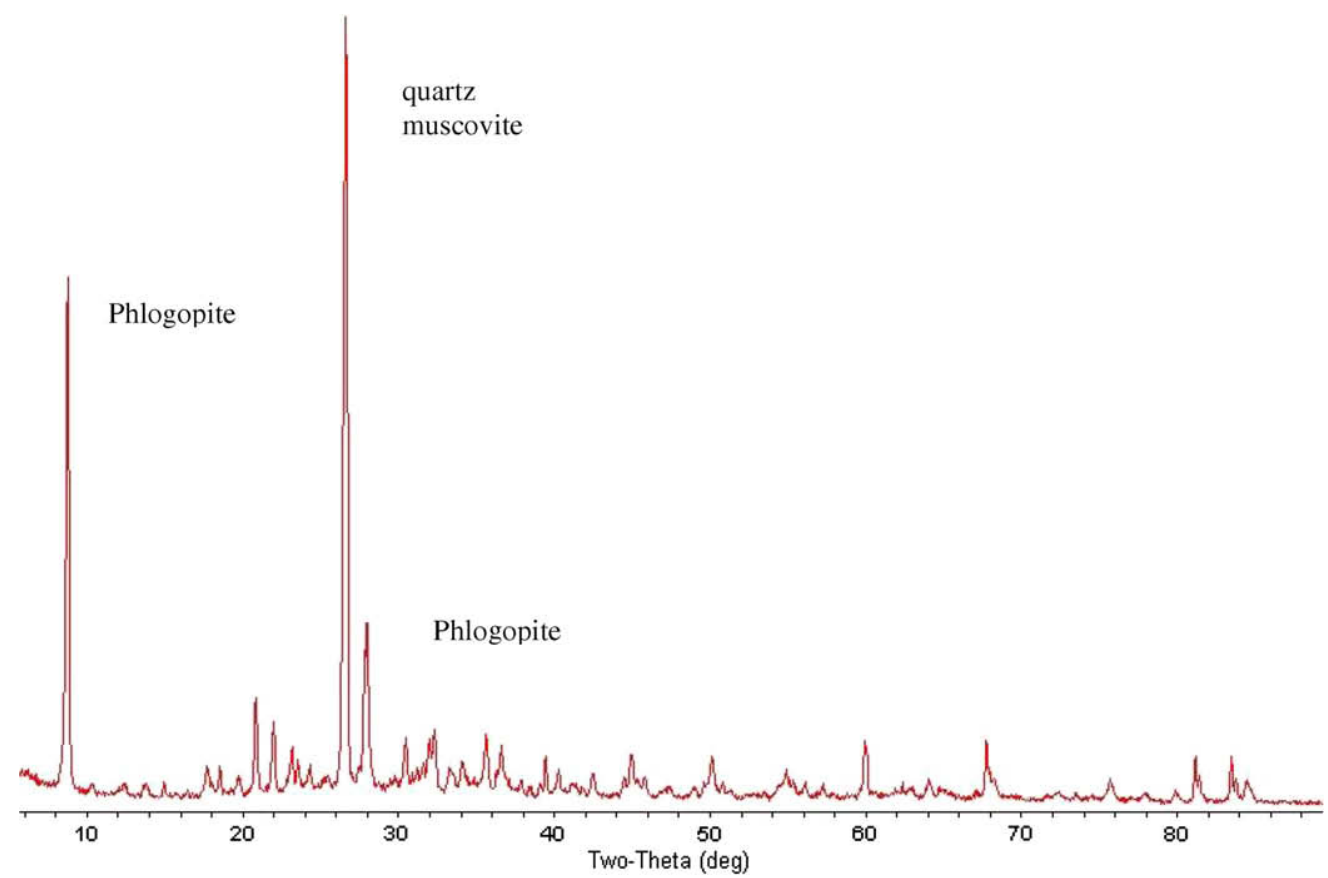

Fig. 5. XRD pattern of GR mortar with granitic aggregates and $10 \%$ calcium hydroxide activated with waterglass and $24 \mathrm{M} \mathrm{NaOH}$ solution. 
the occurrence of shrinkage cracking near the aggregates, originating a clear tensile strength reduction. And a third explanation is related to the formation of gel similar to what takes place in ASR of Portland cement binders, being that the gel volume increase would explain strength loss. Nevertheless, other authors believe that strength loss with curing time, it is related to the fact that $\mathrm{CSH}$ reaction and the geopolymeric reaction will compete against each other for soluble silicates, give rise to a binder composed of two porous phases what leads to strength loss [11].
Mixture SC1 (10\% of calcium hydroxide) presents a steady strength behaviour after 28 days curing when it achieves almost the maximum. It has been previously found that percentage was the optimum level. A part from the explanation that an optimum percentage of positive ions such as $\mathrm{Ca}^{++}$need to be present in the framework cavities is related to the need of balancing the negative charge of the aluminate group. However it is still not clear why calcium hydroxide plays such a significant role in the strength of alkali-activated binders.
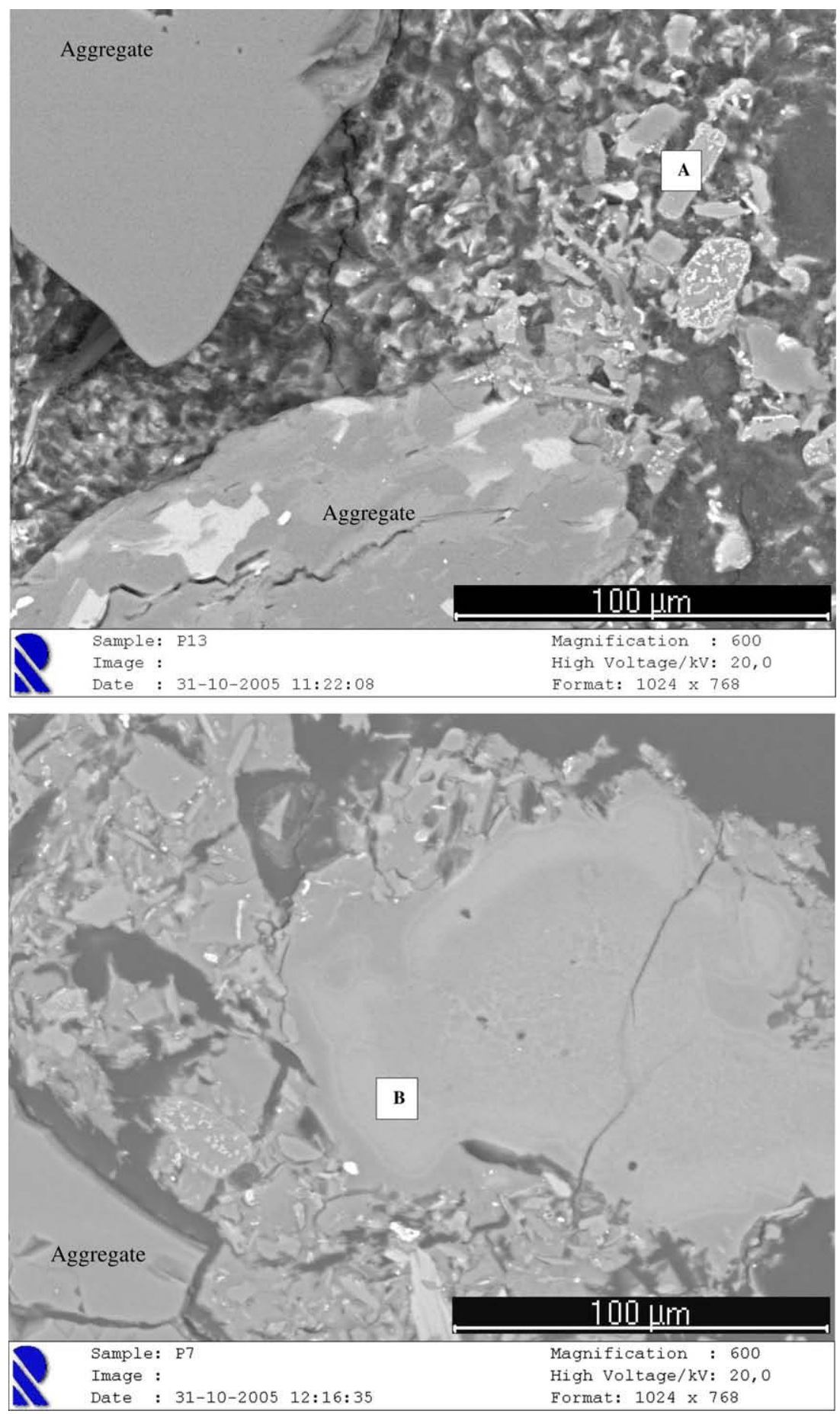

Fig. 6. SEM micrograph of GMWM mortars cured at room temperature during 56 days. 

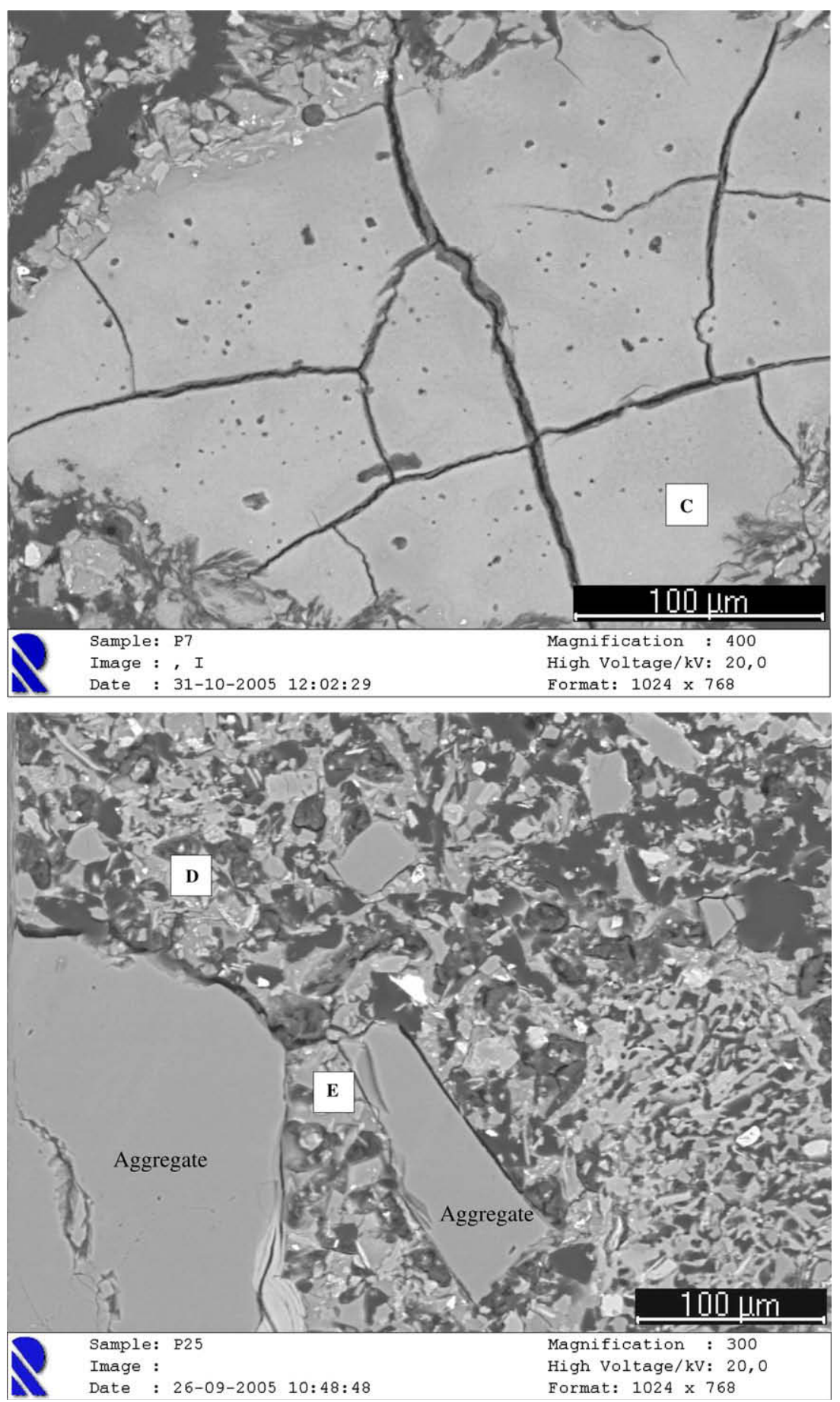

Fig. 6 (continued)

\subsection{X-ray diffraction of hardened GMWM binders}

Figs. 2-5 show XRD patterns of GMWM binders at 56 days curing analysed in the Section 3.1 and with 56 days curing. The results in compressive strength correlate well with hydration products detected in XRD diffraction. The presence of the characteristic peaks of the original mine waste after geopolymerization indicates they have not dissolved completely. Mixture SC2 presents a XRD pattern very similar to the dehydroxylated mine waste mud powder which is in agreement with the low strength at 56 days curing. For the rest of the mixtures XRD patterns show that a new crystalline phase was formed. Phlogopite, a trioctahedral layered structure which is a mineral with a general formula $\mathrm{KMg}_{3}\left(\mathrm{Si}_{3} \mathrm{Al}\right) \mathrm{O}_{10}(\mathrm{OH})_{2}$ in which $\mathrm{Mg}^{2+}$ can be sometimes replaced by $\mathrm{Fe}^{2+}$. One can see that mixtures with increase compressive strength show increase Phlogopite crystalline phase, so it could be expected that 

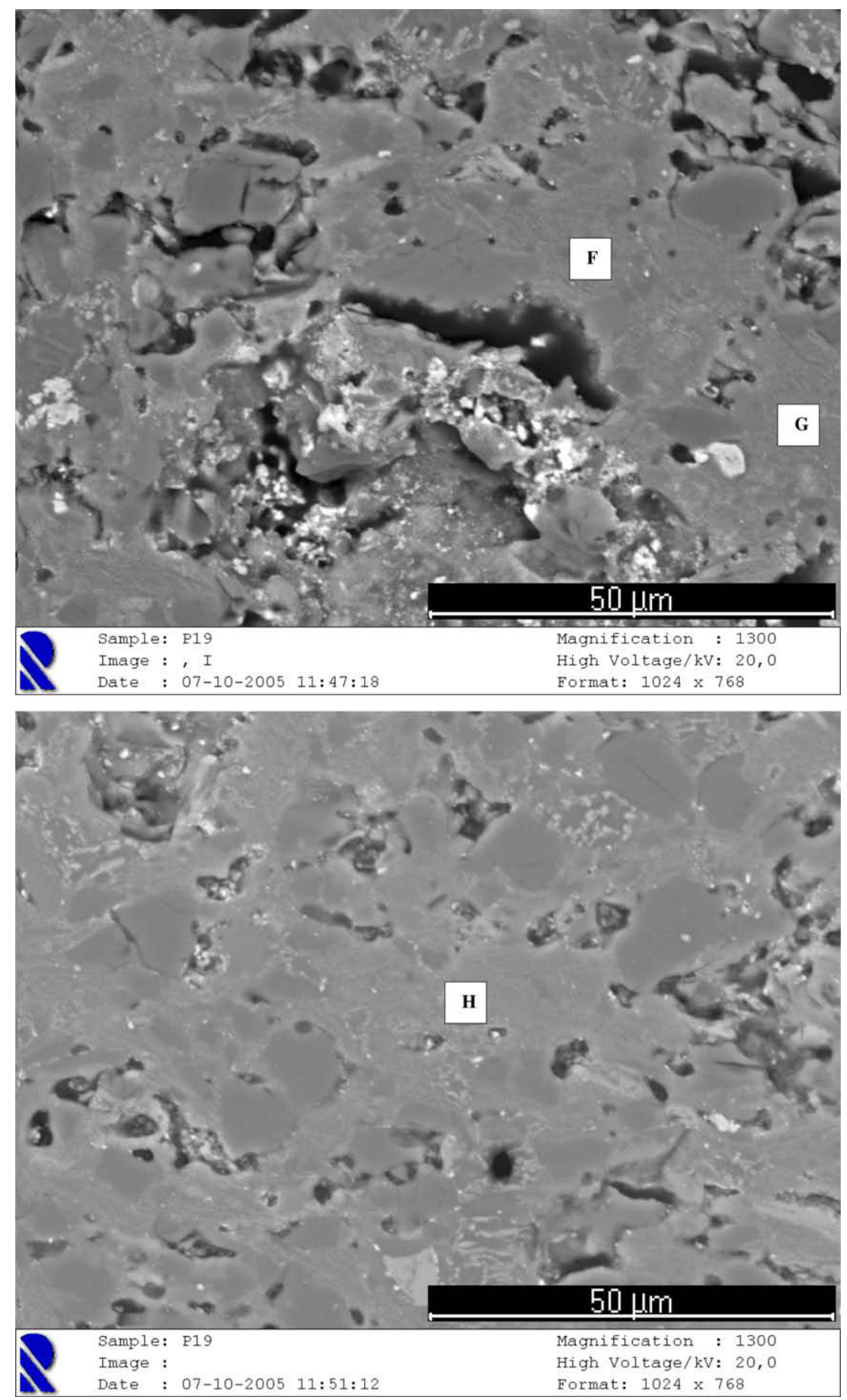

Fig. 6 (continued)

phase contributes some how to strength behaviour of GMWM binders. No crystalline phases containing alkali cations could be identified in XRD patterns.

\subsection{Microstructure of hydration products}

Fig. 6 shows SEM micrographs of GMWM binders. The analysis carried out by EDS on the different samples is displayed in Tables 4 and 5 .
In samples P13 and P7 large voids filled with epoxy resin can be seen, revealing low hydration due to the fact that the optimum calcium hydroxide content was not used in the composition of the mixtures.

Sample P7 shows a high level of cracking. It is thought that may be due to high shrinkage changes that are common on mixtures with a high content of calcium hydroxide. Crystals of the Phlogopite phase detected in XRD patterns that could not be differentiated in SEM observations may be due to his micrometer scale. 


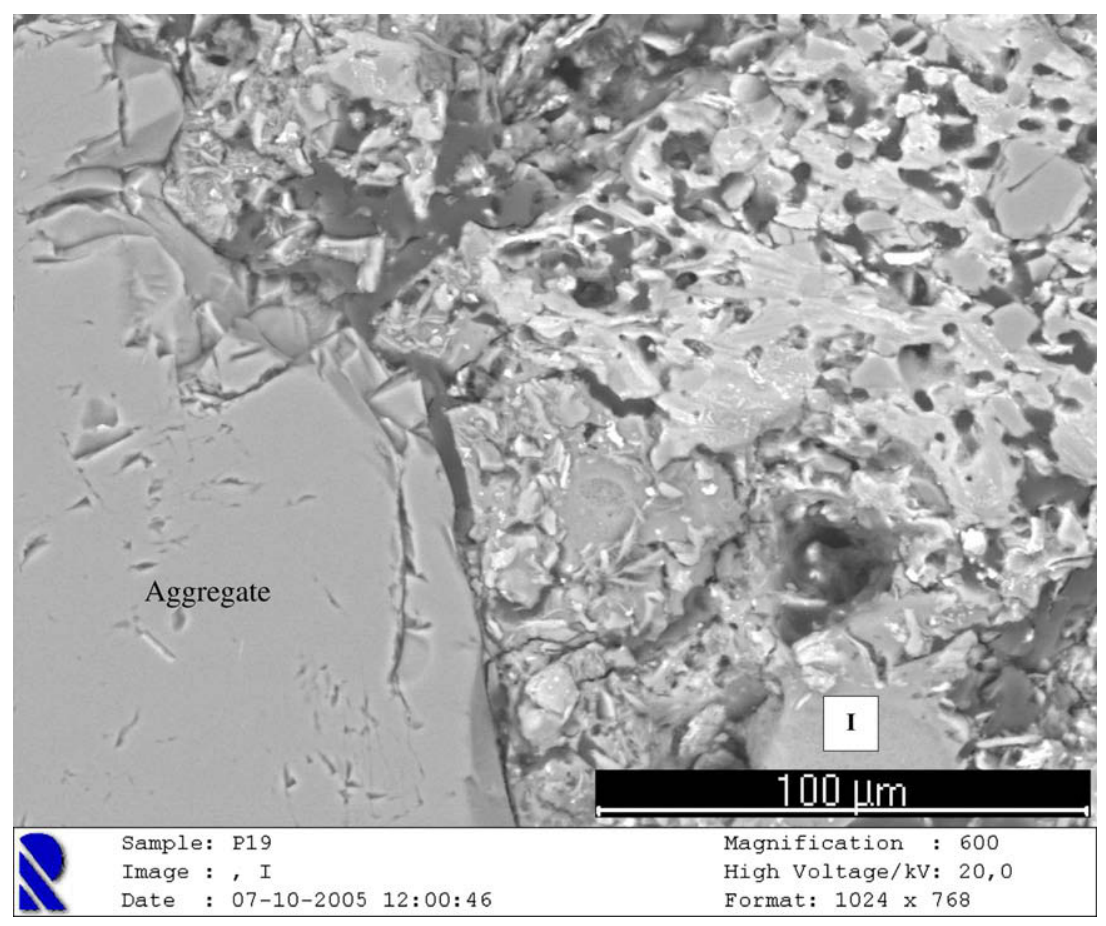

Fig. 6 (continued)

Table 4

EDS analysis

\begin{tabular}{|c|c|c|c|c|c|c|c|c|c|}
\hline & \multirow{2}{*}{$\begin{array}{l}\text { P13 } \\
\text { A }\end{array}$} & \multicolumn{2}{|l|}{ P7 } & \multicolumn{2}{|l|}{ P25 } & \multicolumn{4}{|l|}{ P19 } \\
\hline & & B & $\mathrm{C}$ & D & E & $\mathrm{F}$ & $\mathrm{G}$ & $\mathrm{H}$ & I \\
\hline $\mathrm{SiO}_{2}$ & 43.4 & 47.1 & 45.6 & 60.6 & 61.7 & 59.4 & 52.9 & 60.2 & 46.9 \\
\hline $\mathrm{Al}_{2} \mathrm{O}_{3}$ & 32.8 & - & - & 9.9 & 10.2 & 25.0 & 29.2 & 24.8 & 3.9 \\
\hline $\mathrm{Fe}_{2} \mathrm{O}_{3}$ & 12.9 & - & - & 4.3 & 4.5 & 4.8 & 6.9 & 5.0 & - \\
\hline $\mathrm{K}_{2} \mathrm{O}$ & 4.6 & - & 1.6 & 3.1 & 3.8 & 6.9 & 6.0 & 5.9 & 1.7 \\
\hline $\mathrm{CaO}$ & - & 50.0 & 47.4 & 15.4 & 14.4 & - & - & - & 36.2 \\
\hline $\mathrm{MgO}$ & 3.7 & - & - & - & - & 2.4 & 3.2 & 2.3 & - \\
\hline $\mathrm{Na}_{2} \mathrm{O}$ & 1.3 & 2.9 & 5.4 & 6.7 & 5.4 & 1.5 & 1.8 & 1.8 & 8.4 \\
\hline $\mathrm{TiO}_{2}$ & 1.3 & - & - & - & - & - & - & - & - \\
\hline $\mathrm{SO}_{3}$ & - & - & - & - & - & - & - & - & 2.9 \\
\hline
\end{tabular}

Table 5

Atomic ratio analysis

\begin{tabular}{|c|c|c|c|c|c|c|c|c|c|c|}
\hline \multirow[t]{2}{*}{ Atomic ratio } & \multirow{2}{*}{$\begin{array}{l}\text { Mine } \\
\text { waste } \\
\text { mud }\end{array}$} & \multirow{2}{*}{$\begin{array}{l}\text { P13 } \\
\text { A }\end{array}$} & \multicolumn{2}{|l|}{$\mathrm{P} 7$} & \multicolumn{2}{|l|}{ P25 } & \multicolumn{4}{|c|}{ P19 } \\
\hline & & & B & $\mathrm{C}$ & $\mathrm{D}$ & $\mathrm{E}$ & $\mathrm{F}$ & G & $\mathrm{H}$ & I \\
\hline $\mathrm{O}_{2} / \mathrm{Al}_{2} \mathrm{O}_{3}$ & 5.5 & 2.3 & - & - & & 10.4 & 4.0 & 3.1 & 4.2 & \\
\hline $\mathrm{Al}_{2} \mathrm{O}_{3} / \mathrm{Na}_{2} \mathrm{Oeq}$ & 1.8 & 4.5 & - & - & 7 & 0.8 & 2.5 & 3.1 & 2.6 & 0.3 \\
\hline $\mathrm{CaO} / \mathrm{SiO}_{2}$ & - & - & 1.1 & 1.1 & 0.3 & 0.3 & - & - & - & 0.8 \\
\hline $\mathrm{Na}_{2} \mathrm{Oeq} / \mathrm{CaO}$ & - & - & 0.05 & 0.03 & 0.5 & 0.5 & - & - & - & 0.2 \\
\hline $\mathrm{Al}_{2} \mathrm{O}_{3} / \mathrm{CaO}$ & - & - & - & - & 0.4 & 0.4 & - & - & - & 0. \\
\hline $\mathrm{MgO} / \mathrm{Al}_{2} \mathrm{O}_{3}$ & 0.2 & 0.3 & - & - & - & - & 0.3 & 0.3 & 0.3 & - \\
\hline $\mathrm{Fe}_{2} \mathrm{O}_{3} / \mathrm{Al}_{2} \mathrm{O}_{3}$ & 0.5 & 0.3 & - & - & 0.3 & 0.3 & 0.1 & 0.1 & 0.1 & - \\
\hline
\end{tabular}

The $\mathrm{SiO}_{2} / \mathrm{Al}_{2} \mathrm{O}_{3}$ in areas marked as $\mathrm{A}, \mathrm{F}, \mathrm{G}, \mathrm{H}$, is lower than in the waste mud due to increased aluminium content. Therefore, authors believe that some aluminium will be dissolved from the aggregates to participate in the geopolymerization process. That hypothesis is consistent with the behaviour presented by binders with aluminosilicate aggregates (GR) which present higher compressive strength. $\mathrm{Si}-\mathrm{O}-\mathrm{Si}$ linkages are stronger than $\mathrm{Si}-\mathrm{O}-\mathrm{Al}$ bonds, which means that geopolymers strength should increase with $\mathrm{Si} /$ $\mathrm{Al}$ ratio. Puertas et al. [17] found similar $\mathrm{Al} / \mathrm{Si}$ ratios in alkali-activated slag cement pastes and suggest that it is due to substitution of $\mathrm{Si}$ by $\mathrm{Al}$ in tetrahedral positions in the silicate chain. Other authors working with high $\mathrm{SiO}_{2} /$ $\mathrm{Al}_{2} \mathrm{O}_{3}$ molar ratio metakaolin found out that hydration products developed during geopolymerization have lower $\mathrm{SiO}_{2} / \mathrm{Al}_{2} \mathrm{O}_{3}$ molar ratio than in the original precursor material [18]. This is related to the fact that not all the silica and alumina are reactive. So even despite the fact $\mathrm{Al}$ and $\mathrm{Si}$ have synchro-dissolution behaviour in alkaline solution, which means they dissolve from the mineral in some linked form, one can not expect the same $\mathrm{Si} / \mathrm{Al}$ ratio in the final hydration product as the one present in the original precursor material. Besides, it must be taken into account that previous investigations showed that mine waste mud, like others Al-Si materials, cannot supply sufficient $\mathrm{Si}$ in alkaline solution to start geopolymerization this is why it needs, extra silica provided in solution by waterglass, which also influences the $\mathrm{Si} / \mathrm{Al}$ ratio of the hardened GMWM binder.

The samples P13 and P7 have almost the same composition and have been submitted to the same alkali silicate solution. The difference is only the calcium hydroxide content, respectively 5 and $25 \%$ which is responsible for the very different products detected in the microstructural analysis. While the areas marked as A consisted mainly of silicon, aluminium, with no traces of calcium, and could be considered unreacted mine waste or a schist particle. The areas marked as $\mathrm{B}$ and $\mathrm{C}$ are chemically very similar and consisted mainly 
of silicon, calcium and some sodium being some form of calcium precipitate, as expected from the low solubility of calcium hydroxide in high alkaline medium. The existence of those calcium precipitates helps to explain the low strength of the mixture P7. Similar considerations could be made about area I in sample P19.

Areas marked as D and E in sample P25 seem to be some type of calcium silicate and consisted mainly of silicon, calcium and some sodium. EDS analysis show that $\mathrm{Al} / \mathrm{Ca}$ molar ratio $\left(\mathrm{Al}_{2} \mathrm{O}_{3} / \mathrm{CaO}\right)$ is similar to $\mathrm{Na} / \mathrm{Ca}$ in sample $\mathrm{P} 25$ so the amount of sodium is just enough to play a charge-balancing role for aluminium to substitute for silicon in the structure.

Areas F, G and $\mathrm{H}$ in sample P19 are very dense and uniform could be considered some form of alkali aluminosilicate gel. This finding confirms the formation of geopolymeric gel as the main reaction product of Al-Si materials in presence of calcium hydroxide when submitted to high alkaline solutions.

\section{Conclusions}

The following conclusions can be drawn from this study:

- Mechanical strength as a function of the concentration of the alkaline activator and percentage substitution of calcium hydroxide is closely related to the mineralogy of the hardened GMWM binders.

- Results show that a new crystalline phase, phlogopite a trioctahedral layered structure, was formed as a result of the geopolymerization process in GMWM binders.

- SEM and EDS analysis indicates that hydration products were aluminosilicate gel and calcium silicate hydrates.

- Crystals of phlogopite could not be differentiated in SEM observations.

- Further investigations using infrared spectroscopy (FTIR) are needed in order to better understand structural changes related to hydration products of GMWM binders.

\section{Acknowledgements}

The authors would like to thank to the Optical Centre of University of Beira Interior for helping in XRD and SEM/ EDS investigations.

\section{References}

[1] Glukhovsky VD. Soil silicates. Kiev, USSR: Gostroiizdat Publisher; 1959.

[2] Shao-Dong Wang, Karen Scrivner. Hydration products of alkali activated slag cement. Cement Concrete Res 1995;25:561-71.

[3] Song S, Sohn D, Jennings HM, Mason TO. Hydration of alkaliactivated ground granulated blast furnace slag. Mater Sci 2004;35: 249-57.

[4] Pu X, Gan C, Wu L. Properties of alkali-slag cement concrete. J Chin Ceram Soc 1989(5):5-10.

[5] Davidovits J. Mineral polymers and methods of making them, US Patent 1982; 4349386

[6] Davidovits J. Geopolymers: inorganic polymeric new materials. J Therm Anal 1991;37:1633-56.

[7] Fernandez Jimenez A, Palomo A. Composition and microstructure of alkali activated fly ash binder: effect of the activator. Cement Concrete Res 2005;35:1984-92.

[8] Palomo A, Grutzec MW, Blanco MT. Alkali - activated fly ashes. A cement for the future. Cement Concrete Res 1999;29:1323-9.

[9] Slavik R, Bednarik V, Vondruska M, Skoba O, Hanzlicek T. Chemical indicator of geopolymer. Geopolymer 2005 World Congress, pp. 17-19. Saint Quentin. France: 2005.

[10] Alonso S, Palomo A. Alkaline Activation of metakaolin and calcium hydroxide mixtures: influence of temperature, activator concentration and solids ratio. Mater Lett 2001;47:55-62.

[11] Yip CK, Lukey GC, Deventer SJS. The coexistence of geopolymeric gel and calcium silicate hydrate gel at the early stage of alkaline activation. Cement Concrete Res 2005;35:1688-97.

[12] Roy MDella. Alkali - activated cements. Opportunities and challenges. Cement Concrete Res 1999;29:249-54.

[13] Pacheco-Torgal F, Castro-Gomes JP, Jalali S. Investigations on mix design of tungsten mine waste geopolymeric binder. Construct Build Mater, in press, doi:10.1016/j.conbuildmat.2007.07.015.

[14] Pacheco-Torgal F, Castro-Gomes JP, Jalali S. Effect of aggregates on strength and microstructure of geopolymeric mine waste mud binders. Cement Concrete Res 2007;37:933-41.

[15] Pacheco-Torgal F, Castro-Gomes JP, Jalali S. Alkali activated geopolymeric binder using tungsten mine waste: preliminary investigation. In: Proceedings of Geopolymer 2005 World Congress, Saint Quentin France; 2005. pp. 93-98.

[16] Pacheco-Torgal F, Castro-Gomes JP, Jalali S. Adhesion characterization of tungsten mine waste geopolymeric binder. Influence of OPC concrete substrate surface treatment. Construct Build Mater 2008;22: 154-61.

[17] Puertas F, Fernandez-Jimenez A, Blanco-Varela MT. Pore solution in alkali-activated slag cement pastes. Relation to the composition and structure of calcium silicate hydrate. Cement Concrete Res 2004;34: 195-206.

[18] Zhang YS, Sun W, Li JZ. Hydration process of interfacial transition in potassium polysialate (K-PSDS) geopolymer concrete. Mag Concrete Res 2005;57:33-8. 